\title{
Physiological Quality of Soybean Seeds Depending on the Preharvest Desiccation ${ }^{1}$
}

\author{
Qualidade Fisiológica de Sementes de Soja em Função da Dessecação Pré-Colheita
}

PEREIRA, T. ${ }^{2,3}$, COELHO, C.M.M. ${ }^{3}$, SOBIECKI, M. ${ }^{3}$, and SOUZA, C.A. ${ }^{3}$

\begin{abstract}
Depending on the cultivar, the use of desiccants in the preharvest can favor maintenance of physiological quality. The objective of the study was to assess the physiological quality of soybean seeds as due to the use of apreharvest desiccant and desiccation time in two harvests $(2011 / 12$ and 2012/13). The treatments were five soybean cultivars, two growth stages of application, a control (without desiccant application), and three desiccants (glufosinate-ammonium, carfentrazone-ethyl and paraquat) (2011/12 harvest). In the 2012/ 13 harvest the carfentrazone-ethyl desiccant was replaced by diquat. The physiological quality of seeds was assessed by the percentage of viability and vigor (cold test, tetrazolium test and accelerated aging test). In 2011/12 harvest, there was an early harvest in six days with the use of glufosinate-ammonium and paraquat desiccants, when desiccation was done in stage R7.1, with maintenance of seed quality; however it was dependent on the cultivar. In the 2012/13 harvest there was no early harvesting due to the presence of rain in the preharvest and the use of desiccation did not affect the physiological quality of the seeds either. Cultivar NA5909 RG was more tolerant to remaining in the cultivation environment and maintained higher viability than $90 \%$ and greater vigor of $71 \%$ by the cold test compared to cultivar BMX Turbo (2011/12 harvest). It is concluded that desiccation can be a viable alternative to the soybean early harvesting, but it depends on the cultivar, the time of desiccation, the active principle of the desiccant and the absence of rain in preharvest.
\end{abstract}

Keywords: Glycine max, viability, desiccant, vigor.

RESUMO - O uso de dessecantes em pré-colheita pode favorecer a manutenção da qualidade fisiológica das sementes de soja. Assim, o objetivo deste trabalho foi avaliar a qualidade fisiológica de sementes de cultivares de soja em função do uso de dessecantes em pré-colheita e da época de dessecação, em duas safras (2011/12 e 2012/13). Os tratamentos consistiram no uso de cinco cultivares de soja, dois estádios fenológicos de aplicação, uma testemunha (sem aplicação de dessecante) e três dessecantes (glufosinato de amônio, carfentrazona-etílica e paraquat) (safra 2011/12). Na safra 2012/13, o dessecante carfentrazona-etílica foi substituido por diquat. A qualidade fisiológica das sementes foi avaliada pelo percentual de viabilidade e vigor (teste de frio, tetrazólio e envelhecimento acelerado). Na safra 2011/12, houve antecipação da colheita em seis dias com o uso dos dessecantes glufosinato de amônio e paraquat, quando a dessecação foi feita no estádio R7.1, com manutenção da qualidade fisiológica das sementes, porém foi dependente do cultivar. Na safra 2012/13 não houve antecipação de colheita em função da ocorrência de chuvas na pré-colheita, e o uso da dessecação não afetou a qualidade fisiológica das sementes. O cultivar $N A 5909$ RG foi mais tolerante à permanência no ambiente de cultivo e manteve viabilidade superior a 90\% e vigor de 71\%, pelo teste de frio, quando comparado ao cultivar BMX Turbo (safra 2011/12). Conclui-se que a dessecação pode ser uma alternativa viável para a antecipação da colheita de soja, porém ela é dependente do cultivar, da época de dessecação, do princípio ativo do dessecante e da ausência de chuvas em pré-colheita.

Palavras-chave: Glycine max, viabilidade, dessecante, vigor.

Recebido para publicação em 17.1.2015 e aprovado em 13.3.2015.

UNOESC. Campos Novos-SC, Brasil; ${ }^{3}$ UDESC. Lages-SC, Brasil <cileide.souza@udesc.br>. 


\section{INTRODUCTION}

The municipality of Campos Novos is one of the largest soybean producers in the Brazilian State of Santa Catarina. It produced 80,000 tonnes of seeds in the 2013/14 harvest, which represented about $40 \%$ of the state yield (Aprosesc, 2014).

In seed production fields, the main objective, combined with productivity, is to obtain a high physiological quality. The maximum quality of seeds, i.e., maximum germination and vigor, is reached at the physiological maturity point. Therefore, the ideal seed crop would be the one as close to that time. However, at this stage, the high percentage of water in the seeds (50-55\%) (França Neto, 1984) and the high number of green leaves hinders an efficient crop without mechanical damage.

Generally, the delayed harvest, associated with seeds exposure to relative humidity, temperature and rainfall variations, negatively influences the quality. According to Diniz et al. (2013), the harvest delayed in 30 days after stage $\mathrm{R} 8$ reduced germination and vigor, and cultivars responded differently to this condition. This shows the importance of assessing the response of different cultivars on seed physiological quality in delayed corp conditions.

Thus, an alternative that the seed producer has to minimize the deterioration in the fields and preserve the quality is the early harvesting or timing. In commercial areas of production this can be obtained with the use of desiccants in preharvest, which can ensure better physiological and sanitary quality of seeds (Lacerda et al., 2005).

Early harvesting by desiccation reduces the possibility of damage caused by pests and fungi, promotes uniformity of maturation, enables control of adult weeds, reduces impurities and improves crop efficiency, besides making the area available for other crops (Inoue et al., 2003; Griffin et al., 2010). However, it is important to know the product's mode of action, application phenological stage, the behavior of cultivars and their growth habit (Zagonel, 2011).

Moreover, some herbicides used in preharvest desiccation can leave residues, which may cause reduction in vigor or germination (Daltro et al., 2010) or even promote rapid growth of fungi, depending on the weather conditions at the time of application (Whigham \& Stoller, 1979).

Regarding the indication of chemical desiccation, there are conflicting results related to the effect of desiccation on yield and physiological quality of soybean seeds. The yield of soybean can be reduced by the use of desiccants when the application occurs before the physiological maturity (Ratnayake \& Shawn, 1992; Lamego et al., 2013); in indeterminate growth habits of cultivars, the pods are still being formed after the physiological maturity and it is recommended that the desiccation takes place after stage R8 (Zagonel, 2011). Conversely, Guimarães et al. (2012) have observed that preharvest desiccation prior to physiological maturity (R6) has not affected yield.

According to Bennett \& Shaw (2000), the germination of cultivar NK4260 G was reduced with the use of glyphosate and paraquat desiccants in stages R5, R6 and R7, when compared to stage R8. As for Lamego et al. (2013), they have observed that germination, field emergence and emergence speed index (ESI) in seeds derived from paraquat use in stage R6 were higher than at stages R7.3.

Based on the assumption that, depending on the cultivar, the use of desiccants can promote the maintenance of physiological quality, the aim of this study was to assess the seeds physiological quality in different soybean cultivars, depending on preharvest use of desiccants and the time of desiccation, in two agricultural harvests.

\section{MATERIALS AND METHODS}

Experiments were conducted in agricultural years 2011/12 and 2012/13, in the Brazilian municipality of Campos Novos, SC, with geographic coordinates $24^{\circ} 24^{\prime}$ of south longitude and $51^{\circ} 13^{\prime}$ of west longitude and approximately $925 \mathrm{~m}$ of altitude (Duflhot et al., 2005).

The experimental design used in both harvests was completely randomized, with four replications. The treatments were 
arranged in a factorial arrangement with an additional treatment [ $(5 \times 2 \times 3)+1]$, being five soybean cultivars: NA 5909 RG, CD 2585 RR, BMX Turbo RR, SYN 1059 RR and BENSO 1RR; two phenological stages (R7.1 and R7.3); three desiccants: glufosinate-ammonium, paraquat and carfentrazone-ethyl; and a control (without application of desiccant). In the 2012/13 harvest, the carfentrazone-ethyl desiccant was replaced by diquat.

The soybean cultivars used in the experiment have indeterminate habits, except cultivar BENSO 1RR, which has determinate habits and belong to the following maturation groups: 5.8 (BMX Turbo RR, CD 2585 RR), 5.9 (SYN $1059 \mathrm{RR}$ ) and 6.1 (NA $5909 \mathrm{RG}$ and BENSO 1RR).

The experimental plots were composed of 10 rows measuring 13 meters, spaced $50 \mathrm{~cm}$, totaling $65 \mathrm{~m}^{2}$. The floor area corresponded to the four $5.5 \mathrm{~m}$ long central rows; $3.75 \mathrm{~m}$ were neglected at each end of the plot, totaling an area of $11 \mathrm{~m}^{2} .13$ viable seeds were sown per linear meter, which resulted in a density of 260,000 plants per hectare.

The fertilization at planting was $8 \mathrm{~kg} \mathrm{ha}^{-1}$ of $\mathrm{N}, 96 \mathrm{~kg} \mathrm{ha}^{-1}$ of $\mathrm{P}_{2} \mathrm{O}_{5}$ and $48 \mathrm{~kg} \mathrm{ha}^{-1}$ of $\mathrm{K}_{2} \mathrm{O}$, based on soil analysis for yield potential of $4 \mathrm{t} \mathrm{ha}^{-1}$, according to technical recommendations from Comissão de Química e Fertilidade do Solo (Chemical and Soil Fertility Commission) (CQFS-RS/SC, 2004). Crop management with control of pests and diseases was conducted in accordance with the technical specifications for the soybean crop in the states of Rio Grande do Sul and Santa Catarina 2012/2013 (Embrapa, 2012). Daily precipitation and temperature data for the place of crop were obtained by Epagri/ Ciram (2014).

To identify the phenological stages of plant development, there were periodic visits in the experimental area, where color of pods and leaves is assessed and compared with the scale by Ritchie et al. (1982); furthermore, water content of the seeds was determined.

Applying the desiccants was done when the plants were in phenological stages R7.1, characterized as physiological maturity (start at $50 \%$ yellowing of leaves and pods), e R7.3, i.e. more than $75 \%$ of leaves and yellow pods, according to the scale by Ritchie et al. (1982). Water content of seeds in phenological stage R7.1 was around 50\% (2011/ 12 harvest) and 60\% (2012/ 13 harvest). As for stage R7.3, seeds had water content of about 25\% (2011/ 12 harvest) and 30\% (2012/13 harvest).

Herbicide application (desiccants) was performed with a mechanical spray model Patriot 350 (Case), with flow of $300 \mathrm{~L} \mathrm{ha}^{-1}$ and fan type nozzles. In the process of applying the desiccant, two sections of the spray boom were used, amounting to $8.6 \mathrm{~m}$ long. The applications of desiccants were done in the morning.

Desiccants used in the 2011/12 harvest were: glufosinate-ammonium $2.0 \mathrm{~L} \mathrm{ha}^{-1}+0.2 \%$ of Hoefix (sticker spreader); paraquat $\left(2.0 \mathrm{~L} \mathrm{ha}^{-1}\right)$ and carfentrazone-ethyl (125 $\mathrm{mL} \mathrm{ha}^{-1}+0.5 \%$ of mineral oil). In the 2012/13 harvest, herbicide carfentrazoneethyl was replaced by diquat, which was used in a dose of $2.0 \mathrm{~L} \mathrm{ha}^{-1}+0.2 \%$ of Hoefix (spreader sticker).

The harvest in the floor area of each plot was carried out manually, and for the threshing of the pods a stationary threshing machine was used. The criteria used to harvest the plots was based on monitoring visual characteristics of maturity of the plants and when the moisture content of the seeds was close to $14 \%$, both for the desiccated plots in preharvest, and the control which was not desiccated.

The harvest in $2011 / 12$ occurred on the following dates: 04/03/2013 - stage R7.1, desiccants: glufosinate-ammonium and paraquat; 04/10/2013 -stage R7.1, desiccant: carfentrazone-ethyl; and stage R7.3, for all desiccants and control. In the 2012/13 harvest, the crop was done on 04/01/2013, for all treatments. The seeds were placed in a $6.5 \mathrm{~mm}$ sieve and an average sample of $2 \mathrm{~kg}$ was obtained, from which the work sample was taken to do the physiological quality tests.

In the assessment of the physiological quality, feasibility (tetrazolium) and vigor analyzes were performed by accelerated aging, cold test and tetrazolium. For the accelerated aging test (AA), seeds were distributed on aluminum screens and fixed inside plastic boxes, adding $40 \mathrm{~mL}$ of water. The boxes were 
sealed and kept in an aging chamber for $48 \mathrm{~h}$ (2011/12 harvest) or $72 \mathrm{~h}(2012 / 13$ harvest) at a temperature of $42{ }^{\circ} \mathrm{C}$ (Krzyzanowski et al., 1999). Then the seeds were germinated at $25^{\circ} \mathrm{C}$ and, after five days, a count of normal seedlings was done (Brasil, 2009).

Cold test (CT) was performed using four subsamples of 50 seeds from each treatment, distributed on germitest paper and placed in plastic bags at $10{ }^{\circ} \mathrm{C}$ for a period of five days for the 2011/12 harvest (Krzyzanowski et al., 1999) and adapted for eight days in the 2012/ 13 harvest. After these periods, the samples were removed from the plastic bags and placed in a germinator at $25^{\circ} \mathrm{C}$ for five days, when the counting of normal seedlings was done (Brasil, 2009).

Tetrazolium test (TZ) was conducted with two samples of 50 seeds that were prepackaged in germitest paper moistened with distilled water for 16 hours. After this period, the seeds were immersed in a $0.075 \%$ solution of 2,3,5-triphenyl tetrazolium chloride (TTC), which was taken to the oven at $35^{\circ} \mathrm{C}$ for three hours. After this period, the solution was drained, the seeds were washed and kept in water until the time of test interpretation. The assessment was done according to the categories of vigor and viability, by means of the distribution of seeds in eight categories described by França Neto et al. (1998).

The data were submitted to the ShapiroWilk test (5\%) to verify the normality. The data presented in percentage were transformed into an arcsine of $(\mathrm{x} / 100)^{0.5}$ and then subjected to analysis of variance by $\mathrm{F}$ test at $5 \%$ significance level. The means of the desiccants, cultivars and application stages were compared by Tukey test at $5 \%$ probability. The comparison with the control was carried out by Dunnett's test at $5 \%$ probability (SAS, 2009).

\section{RESULTS AND DISCUSSION}

Based on the analysis of variance, the viability by the tetrazolium test showed significant effects to grow only in the two harvests (2011/2012 and 2012/13), and the vigor by the tetrazolium test of the seeds originating from both agricultural harvests, just a simple effect for cultivar and desiccant (Table 1). The vigor by accelerated aging and cold test was influenced by cultivar, desiccant and application stage, presenting triple interaction only in the 2012/13 harvest.

The vigor by cold test and accelerated aging arising from the $2011 / 12$ harvest showed interaction between desiccant and phenological stage and between cultivar and desiccant (Table 1); in addition, accelerated aging also showed interaction between cultivar and time, demonstrating that the effect of the desiccant depends on its application stage and the cultivar response depends on the desiccant used; in the case of

Table 1 - Analysis of variance of the seeds physiological quality data in different soybean cultivars, for the 2011/12 and 2012/13 harvests, due to the application of desiccants and the phenological stage of the plant, in the municipality of Campos Novos, SC

\begin{tabular}{|c|c|c|c|c|c|c|c|c|}
\hline \multirow{2}{*}{ SV } & \multicolumn{4}{|c|}{ 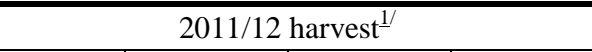 } & \multicolumn{4}{|c|}{ 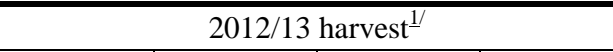 } \\
\hline & $\mathrm{V}$ & AA & CT & $\mathrm{TZ}$ & V & AA & $\mathrm{CT}$ & $\mathrm{TZ}$ \\
\hline Cultivars (C) & $0.04 *$ & $0.05^{*}$ & $0.12 *$ & $0.12 *$ & $0.04 *$ & $0.29 *$ & $0.26 *$ & $0.02 *$ \\
\hline Desiccant (D) & $0.08 *$ & $0.39 *$ & $0.14^{*}$ & $0.16^{*}$ & 0.004 & $0.27 *$ & $0.24 *$ & $0.03^{*}$ \\
\hline Phenological stage (E) & $0.09 *$ & 0.010 & 0.008 & 0.03 & 0.00003 & $0.33 *$ & $0.08 *$ & 0.003 \\
\hline C X D & $0.03 *$ & $0.011^{*}$ & $0.29 *$ & 0.02 & 0.01 & 0.006 & $0.05^{*}$ & 0.008 \\
\hline C X E & 0.01 & $0.03 *$ & 0.01 & 0.02 & 0.006 & 0.019 & $0.10 *$ & 0.010 \\
\hline DXE & 0.02 & $0.11 *$ & $0.16^{*}$ & 0.09 & 0.019 & $0.25 *$ & $0.39 *$ & 0.007 \\
\hline C X D X E & 0.02 & 0.007 & 0.008 & 0.02 & 0.010 & $0.034 *$ & $0.11^{*}$ & 0.006 \\
\hline Control & $0.04 *$ & $0.014 *$ & $0.04 *$ & $0.01^{*}$ & 0.008 & $0.030 *$ & 0.05 & 0.002 \\
\hline Residue & 0.008 & 0.004 & 0.005 & 0.008 & 0.009 & 0.006 & 0.004 & 0.005 \\
\hline
\end{tabular}

SV: source of variation; V: viability percentage (tetrazolium test); AA: accelerated aging, CT: cold test, TZ: vigor (tetrazolium test). ${ }^{1 /}$ Data transformed in arcsine of $(\mathrm{x} / 100)^{0.5}, *$ significant by the $\mathrm{F}$ test $(p<0.05)$. 
vigor by accelerated aging, there is also the dependence on the cultivar.

Analyzing the dependence between factors desiccant and application stage in the $2011 / 12$ harvest, it was observed that the seeds from the application of glufosinateammonium and paraquat desiccants at phenological stage R7.1 showed higher vigor at 77 and $81 \%$, by cold test and accelerated aging, respectively (Table 2). Furthermore, seeds derived from plants in which herbicides glufosinate-ammonium and paraquat were applied in stage R7.1 showed greater vigor than seeds from the plants in which herbicide carfentrazone-ethyl was applied and non-desiccated plants (control) (Table 2). When comparing with the control the physiological quality of seeds derived from plants where glufosinate-ammonium and paraquat desiccants were applied at phenological stage R7.1, there was an increase in the vigor of seeds from desiccation by glufosinate of 18 percentage points by cold test and accelerated aging and for paraquat of 19 percentage points by cold test and 21 percentage points for the accelerated aging test (Table 2).

In addition to the relationship between desiccant and timing of application, it was observed that the seeds of most soybean cultivars coming from desiccation with paraquat in the 2011/12 harvest showed higher vigor (cold test and accelerated aging) than the control (Table 3 ). Viability (tetrazolium test) was maintained in all soybean cultivars analyzed, regardless of the use of glufosinate-ammonium and paraquat desiccants (Table 3).
It is observed that the maintenance of physiological quality is dependent on the cultivars (Table 4). Cultivar IN 5909 RG maintained its physiological quality regardless of early harvesting by using desiccants, demonstrating greater vigor maintenance potential (accelerated aging) even when staying longer in the field (control) (Tables 3 and 4). However, cultivar BMX Turbo RR was what proved to be less tolerant to the environmental impacts of a longer stay in the field because it had the lowest percentage of vigor in seeds from the control (50\%) when compared to desiccants paraquat and glufosinate-ammonium, which anticipated the harvest and maintained 73 and $70 \%$ of vigor, respectively (accelerated aging) (Table 3). Thus, it is clear that, for cultivars BMX Turbo e NA 5909 RG, early harvesting was effective in preserving the seed vigor with the use of paraquat and glufosinateammonium.

The positive effect of using a desiccant such as paraquat on the maintenance of the physiological quality of soybean seeds was observed by Guimarães et al. (2012). Results obtained by these authors demonstrated that soybean seed vigor resulting from desiccation with paraquat in stages R6 and R7.2 was superior to the control by 13.2 and $5.9 \%$, respectively (by the accelerated aging test). However, some authors have obtained opposite results, where the use of herbicides in soybean preharvest negatively influenced the seed quality, as is the case of the experiment conducted by Bulow \& Cruz-Silva (2012), who found that the seeds from the application of paraquat desiccant in stage R7.0 showed vigor

Table 2 - Soybeans vigor percentage (cold test and accelerated aging) due to the use of desiccants in preharvest in two phenological stages of the plants, for the 2011/12 harvest, in the municipality of Campos Novos, SC

\begin{tabular}{|c|c|c|c|c|}
\hline \multirow{3}{*}{ Desiccants } & \multicolumn{4}{|c|}{ Phenological stages of application } \\
\hline & \multicolumn{2}{|c|}{ Cold test (\%) } & \multicolumn{2}{|c|}{ Accelerated aging (\%) } \\
\hline & R 7.1 & R 7.3 & R 7.1 & R 7.3 \\
\hline Control & 63 & 63 & 59 & 59 \\
\hline Carfentrazone-ethyl & $64 \mathrm{Ab}$ & $64 \mathrm{Ab}$ & $55 \mathrm{Bb}$ & $69 \mathrm{Ab}^{*}$ \\
\hline Glufosinate-ammonium & $81 \mathrm{Aa}^{*}$ & $81 \mathrm{Aa}^{*}$ & $77 \mathrm{Aa}^{*}$ & $76 \mathrm{Aa}^{*}$ \\
\hline Paraquat & $82 \mathrm{Aa}^{*}$ & $82 \mathrm{Aa}^{*}$ & $80 \mathrm{Aa}^{*}$ & $74 \mathrm{Ba}^{*}$ \\
\hline
\end{tabular}

Means followed by the same lowercase letters in the column, comparing the desiccants, and uppercase letters in the row, comparing the application stages, do not differ by Tukey test $(p<0.05) .{ }^{*}$ significant difference by Dunnett's test $(p<0.05)$. 
Table 3 - Seed viability and vigor percentages by cold test and accelerated aging test of soybean cultivars with the use of desiccants, in the 2011/12 harvest, in the municipality of Campos Novos, SC

\begin{tabular}{|c|c|c|c|c|c|}
\hline \multirow{3}{*}{ Desiccants } & \multicolumn{5}{|c|}{ Cultivars } \\
\hline & CD 2585 RR & NA 5909 RG & BENSO 1RR & SYN 1059 RR & BMX Turbo RR \\
\hline & \multicolumn{5}{|c|}{ Viability (\%) } \\
\hline Control & 89 & 90 & 92 & 79 & 87 \\
\hline Carfentrazone-ethyl & $94 \mathrm{Aa}^{*}$ & $91 \mathrm{Aa}$ & $87 \mathrm{Aa}$ & $87 \mathrm{Aab}$ & $74 \mathrm{Bb}^{*}$ \\
\hline Glufosinate-ammonium & $97 \mathrm{Aa}^{*}$ & $90 \mathrm{Aa}$ & $95 \mathrm{Aa}$ & $93 \mathrm{Aa}^{*}$ & $91 \mathrm{Aa}$ \\
\hline \multirow[t]{2}{*}{ Paraquat } & $96 \mathrm{Aa}^{*}$ & 95 Аа & 91 Аа & $95 \mathrm{Aa}^{*}$ & $95 \mathrm{Aa}$ \\
\hline & \multicolumn{5}{|c|}{ Accelerated aging (\%) } \\
\hline Control & 56 & 63 & 65 & 59 & 50 \\
\hline Carfentrazone-ethyl & $67 \mathrm{Ab}^{*}$ & $66 \mathrm{Ab}$ & $58 \mathrm{ABb}$ & $60 \mathrm{ABb}$ & $58 \mathrm{Bb}$ \\
\hline Glufosinate-ammonium & $74 \mathrm{BCa}^{*}$ & $84 \mathrm{Aa}^{*}$ & 77 BCa* & $79 \mathrm{ABa}^{*}$ & $70 \mathrm{Ca}^{*}$ \\
\hline \multirow[t]{2}{*}{ Paraquat } & 73 Bab* & $82 \mathrm{Aa}^{*}$ & $77 \mathrm{ABa}^{*}$ & $82 \mathrm{Aa}^{*}$ & $73 \mathrm{Ba}^{*}$ \\
\hline & \multicolumn{5}{|c|}{ Cold test (\%) } \\
\hline Control & 66 & 77 & 59 & 55 & 57 \\
\hline Carfentrazone-ethyl & $80 \mathrm{Aa}^{*}$ & $71 \mathrm{ABb}$ & $58 \mathrm{Cb}$ & $77 \mathrm{Ab}^{*}$ & $67 \mathrm{BCb}$ \\
\hline Glufosinate-ammonium & $83 \mathrm{Aa}^{*}$ & $83 \mathrm{Aa}$ & $74 \mathrm{Ba}^{*}$ & $88 \mathrm{Aa}^{*}$ & $64 \mathrm{Bb}$ \\
\hline Paraquat & $86 \mathrm{Aa}^{*}$ & $80 \mathrm{ABa}$ & $81 \mathrm{ABa}^{*}$ & $78 \mathrm{ABb}^{*}$ & $78 \mathrm{Ba}^{*}$ \\
\hline
\end{tabular}

Means followed by the same lowercase letters in the column, comparing the desiccants, and uppercase letters in the row, comparing the cultivars, do not differ by Tukey test $(p<0.05) .{ }^{*}$ significant difference by Dunnett’s test $(p<0.05)$.

Table 4 - Vigor percentage by the accelerated aging test of seeds of different soybean cultivars according to two phenological stages of application in the 2011/12 harvest, in the municipality of Campos Novos, SC

\begin{tabular}{|c|c|c|c|c|c|}
\hline \multirow{2}{*}{ Phenological stages } & \multicolumn{5}{|c|}{ Cultivars } \\
\cline { 2 - 6 } & CD 2585 RR & NA 5909 RG & BENSO 1RR & SYN 1059 RR & BMX Turbo RR \\
\hline R 7.1 & $74 \mathrm{Aa}^{*}$ & $77 \mathrm{Aa}$ & $65 \mathrm{Bb}$ & $73 \mathrm{Aa}$ & $67 \mathrm{Ba}^{*}$ \\
\hline R 7.3 & $69 \mathrm{BCa}$ & $78 \mathrm{Aa}$ & $77 \mathrm{Aa}$ & $74 \mathrm{ABa}$ & $67 \mathrm{Ca}$ \\
\hline Control & 56 & 63 & 65 & 59 & 50 \\
\hline
\end{tabular}

Means followed by the same uppercase letter in the row, comparing the cultivars, and lowercase letter in the column, comparing the phenological stages, do not differ by Tukey test $(p<0.05)$. * significant difference by Dunnett's test $(p<0.05)$.

(first count of germination), less than the control, with a $37 \%$ reduction. This divergence between the results for vigor and germination may be associated to the time of application of the desiccant, the cultivar analyzed and cultivation environment.

The superiority of the seeds physiological quality from the use of desiccants can be explained by the fact that desiccants glufosinate-ammonium and paraquat applied in stage R7.1 anticipated harvest in seven days, compared to the control. Herbicide carfentrazone-ethyl used in the 2011/12 harvest did not anticipate the harvest of soybean cultivars based on their degradation by the crop, which was proven by Dayan et al. (1997), but this product is still an option for weed tillage, particularly for the control of dicotyledons.

The early harvest is an important factor in maintaining seed quality, since there is sufficient evidence that the delay reduces the physiological quality, as noted by Diniz et al. (2013). These authors found a mean reduction of $16 \%$ in germination and $19 \%$ in emergence on sand, with delay in harvesting of soybean cultivars, demonstrating that the soybean seeds persistence for a longer period of time in the field favors their deterioration. In addition, the advance of the seed deterioration 
rate is associated with genetic characteristics of cultivars and exposure of seeds to adverse conditions of temperature and relative humidity. In this regard, Giurizatto et al. (2003) noted that cultivar Embrapa 4 decreased by $34 \%$ for the percentage of vigor with 14 days of harvest delay after phenological stage R8.

There was weed vigor maintenance from the early harvesting with the use of desiccants paraquat and glufosinate-ammonium (Table 2), i.e., this technique may be indicated for the production of seeds with high physiological quality, which is critical to achieving higher seed vigor and, indirectly, greater productivity in soybean crops, because the higher plants yield with use of high vigor seeds was proven by Scheeren et al. (2010), who found a 9\% increase in productivity with the use of lots of high vigor soybean seeds. Thus, the importance of using techniques that favor the maintenance of physiological quality of soybean seeds is shown, as is the early harvesting with the use of preharvest desiccation, which should be applied at the appropriate stage, with doses and herbicides recommended for the crop.

Soybean cultivars derived from the 2012/ 13 harvest had a viability between 95\% (Benso 1RR and NA 5909 RG) and 98\% (BMX Turbo RR and SYN 1059 RR) and vigor between 87\% (NA $5909 \mathrm{RG}$ ) and 93\% (SYN $1059 \mathrm{RR}$ ) (Table 5), indicating an acceptable potential for all cultivars to be marketed as seeds, for the germination percentage reached the minimum of $80 \%$ for the trade of soybean seeds (Brasil, 2013). Furthermore, it was observed that the vigor by the tetrazolium test of soybean cultivars in the 2012/13 harvest was at least $87 \%$ (NA 5909 RG) (Table 5), which ranks it as very high vigor, according to the values proposed by França Neto et al. (1998); this shows that the soybean cultivars showed high physiological quality.

The desiccant factor in the 2012/13 harvest also showed a simple effect for vigor (tetrazolium). It was observed that the use of desiccants applied in soybean preharvest kept the physiological quality of seeds, and not changing vigor when compared to the control. However, in the 2011/12 harvest, it is observed that the vigor derived from the seeds with the use of glufosinate-ammonium and paraquat was superior to the control and seeds with the use of carfentrazone-ethyl (Table 6).

Better physiological quality of soybean seeds from the use of paraquat and glufosinateammonium was also reported by Guimarães et al. (2012), who found greater vigor of these seeds by the accelerated aging test for paraquat $(83.2 \%)$ and glufosinate-ammonium $(79.3 \%)$ with the application of the desiccants in stage R7.2, compared to the seeds from the control $(74.2 \%)$.

The seeds from the desiccation with the use of paraquat in stage R7.1, in the 2012/13

Table 5 - Percentages of vigor (2011/12 and 2012/13 harvests) and viability (2012/13 harvest) of seeds by the soybean cultivars tetrazolium test, due to the application of different desiccants, in the municipality of Campos Novos, SC

\begin{tabular}{|c|c|c|c|c|c|}
\hline & \multicolumn{5}{|c|}{ \% Viability (tetrazolium) - 2012/13 harvest } \\
\hline & BENSO 1RR & NA5909 RG & BMX TURBO RR & CD 2585 RR & SYN 1059 RR \\
\hline Factors & $95 \mathrm{~B}$ & $95 \mathrm{~B}$ & $98 \mathrm{~A}$ & $97 \mathrm{~A}$ & $98 \mathrm{~A}$ \\
\hline \multirow[t]{2}{*}{ Control } & 97 & 98 & 98 & 100 & 99 \\
\hline & \multicolumn{5}{|c|}{ \% Vigor (tetrazolium) - 2011/12 harvest } \\
\hline Factors & $70 \mathrm{~A}$ & $72 \mathrm{~A}$ & $51 \mathrm{~B}$ & $73 \mathrm{~A}$ & $66 \mathrm{~A}$ \\
\hline \multirow[t]{2}{*}{ Control } & 72 & 72 & 44 & 59 & 56 \\
\hline & \multicolumn{5}{|c|}{ \% Vigor (tetrazolium) - 2012/13 harvest } \\
\hline Factors & $89 \mathrm{AB}$ & $87 \mathrm{~B}$ & $91 \mathrm{AB}$ & $91 \mathrm{AB}$ & $93 \mathrm{~A}$ \\
\hline Control & 92 & 93 & 95 & 95 & 92 \\
\hline
\end{tabular}

Means followed by the same uppercase letter in the row do not differ by Tukey's test $(p<0.05) .{ }^{*}$ significant difference by Dunnett's test $(p<0.05)$. 
harvest, they obtained the greatest vigor when compared to stage R7.3 (accelerated aging test and cold test) in cultivars BMX Turbo RR and SYN 1059 RR (Table 7). This shows, similarly to the first harvest, that the use of desiccants such as paraquat did not harm the seed vigor, because its action is contact and application times occurred after physiological maturity of seeds.

Cultivars Benso 1RR, NA5909 RG and BMX Turbo RR had higher vigor (accelerated aging and cold test) on seeds from the use of paraquat in stage R7.1 and also the control, when compared to other cultivars for the 2012/13 harvest (Table 7), indicating that the use of paraquat in the preharvest has not affected the physiological quality of seeds for these crops. Furthermore, it is observed that the genetic component has also influenced the physiological quality.

The use of desiccants in the harvest (2012/13) did not promote early harvesting due to rainfall (Figure 1). Thus, there was no reduction in seed water content in advance in relation to the control, as observed in the 2011/12 harvest, because the seed water content was balanced with high ambient RH (Figure 1). Rainfall in the state of Santa Catarina, particularly in the Midwest region, is reduced over the months from March to April (average $90 \mathrm{~mm}$ ) (Epagri/Ciram, 2014); therefore it is recommended that the use of

Table 6 - Percentage of seed vigor by the tetrazolium test of different desiccants applied in soybean preharvest, in the 2011/12 and 2012/13 harvests, in the municipality of Campos Novos, SC

\begin{tabular}{|c|c|c|c|}
\hline \multicolumn{5}{|c|}{$2011 / 12$ harvest } \\
\hline Carfentrazone-ethyl & Glufosinate-ammonium & Paraquat & Control \\
\hline 57 B & $71 \mathrm{~A}^{*}$ & $70 \mathrm{~A}^{*}$ & Control \\
\hline \multicolumn{2}{|c|}{$2012 / 13$ harvest } & Paraquat & 93 \\
\hline Diquat & Glufosinate-ammonium & $92 \mathrm{~A}$ & 93 \\
\hline
\end{tabular}

Means followed by the same uppercase letter in the row do not differ by Tukey's test $(p<0.05)$ * significant difference by Dunnett's test $(p<0.05)$.

Table 7 - Vigor percentage by accelerated aging test and cold test of seeds in different soybean cultivars, due to the use of desiccants at different phenological stages in the 2012/13 harvest, in the municipality of Campos Novos, SC

\begin{tabular}{|c|c|c|c|c|c|c|c|}
\hline \multirow{3}{*}{ Cultivars } & \multicolumn{7}{|c|}{$\%$ of vigor (accelerated aging) } \\
\hline & \multicolumn{2}{|c|}{ Glufosinate-ammonium } & \multicolumn{2}{|c|}{ Diquat } & \multicolumn{2}{|c|}{ Paraquat } & \multirow{2}{*}{ Control } \\
\hline & R 7.1 & R 7.3 & R 7.1 & R 7.3 & R 7.1 & R 7.3 & \\
\hline BENSO 1RR & $60 \mathrm{Ca}$ & 1/81 Aa* & $71 \mathrm{Ba}$ & $1 / 84 \mathrm{Aa}^{*}$ & $75 \mathrm{Bab}$ & 1/86 Aa* & 73 \\
\hline NA5909 RG & $52 \mathrm{Cab}^{*}$ & ${ }^{1 /} 64 \mathrm{BCb}$ & $54 \mathrm{Cb}$ & $\underline{1} 74 \mathrm{Aab}$ & $81 \mathrm{Aa}^{*}$ & $73 \mathrm{Ab}$ & 65 \\
\hline BMX TURBO RR & $39 \mathrm{Cc}^{*}$ & $1 / 79 \mathrm{Aa}^{*}$ & $53 \mathrm{BCb}^{*}$ & 1/65 Bbc & 1/34 $8 \mathrm{Aa}^{*}$ & $67 \mathrm{Bbc}$ & 64 \\
\hline CD $2585 \mathrm{RR}$ & 44 Cbc* $^{*}$ & $1 / 53 \mathrm{Bb}$ & $31 \mathrm{Cc}^{*}$ & ${ }^{1 /} 57 \mathrm{Ac}$ & $\underline{1} 67 \mathrm{Ab}$ & $52 \mathrm{Bd}$ & 61 \\
\hline SYN 1059 RR & $35 \mathrm{Bc}^{*}$ & $1 / 59 \mathrm{Ab}$ & $40 \mathrm{Bc}$ & ${ }^{1 /} 57 \mathrm{Ac}$ & ${ }^{1 /} 67 \mathrm{Ab}^{*}$ & $56 \mathrm{Bcd}$ & 50 \\
\hline \multicolumn{8}{|c|}{$\%$ of Vigor (cold test) } \\
\hline BENSO 1RR & $37 \mathrm{Db}^{*}$ & $\underline{1}$ 51 CDab* & $1 / 80 \mathrm{Aa}$ & $62 \mathrm{BCa}$ & ${ }^{1 /} 86 \mathrm{Aa}$ & 31Dc* & 71 \\
\hline NA5909 RG & ${ }^{1 /} 68 \mathrm{Aa}$ & $38 \mathrm{Db}^{*}$ & 44 CDbc* $^{*}$ & ${ }^{1 /} 61 \mathrm{ABa}$ & $\underline{1} / 75 \mathrm{Aab}^{*}$ & 50 BCDb* & 65 \\
\hline BMX TURBO RR & 1/36 Bb* & $21 \mathrm{Bc} *$ & $22 \mathrm{Bd}^{*}$ & ${ }^{1 /} 63 \mathrm{Aa}$ & 1/73 Aab & $26 \mathrm{Bc}^{*}$ & 74 \\
\hline CD $2585 \mathrm{RR}$ & $31 \mathrm{Cb}^{*}$ & ${ }^{1 /} 58 \mathrm{Aa}$ & $56 \mathrm{Bb}$ & ${ }^{1 /} 64 \mathrm{ABa}$ & $1 / 75 \mathrm{Aab}^{*}$ & $67 \mathrm{ABa}^{*}$ & 62 \\
\hline SYN 1059 RR & $27 \mathrm{Db}^{*}$ & $\underline{1} 53 \mathrm{ABab}$ & 37 BCcd* & $33 \mathrm{CDb}^{*}$ & ${ }^{1} / 64 \mathrm{Ab}^{*}$ & $40 \mathrm{BCDbc}$ & 48 \\
\hline
\end{tabular}

Means followed by the same letter, lowercase in the column and uppercase in the row, do not differ by Tukey's test ( $p<0.05)$.

$1 /$ significant difference between the phenological stages within each desiccant by Tukey's test $(p<0.05)$. ${ }^{*}$ significant difference by the Dunnett's test $(p<0.05)$ compared with the control. 


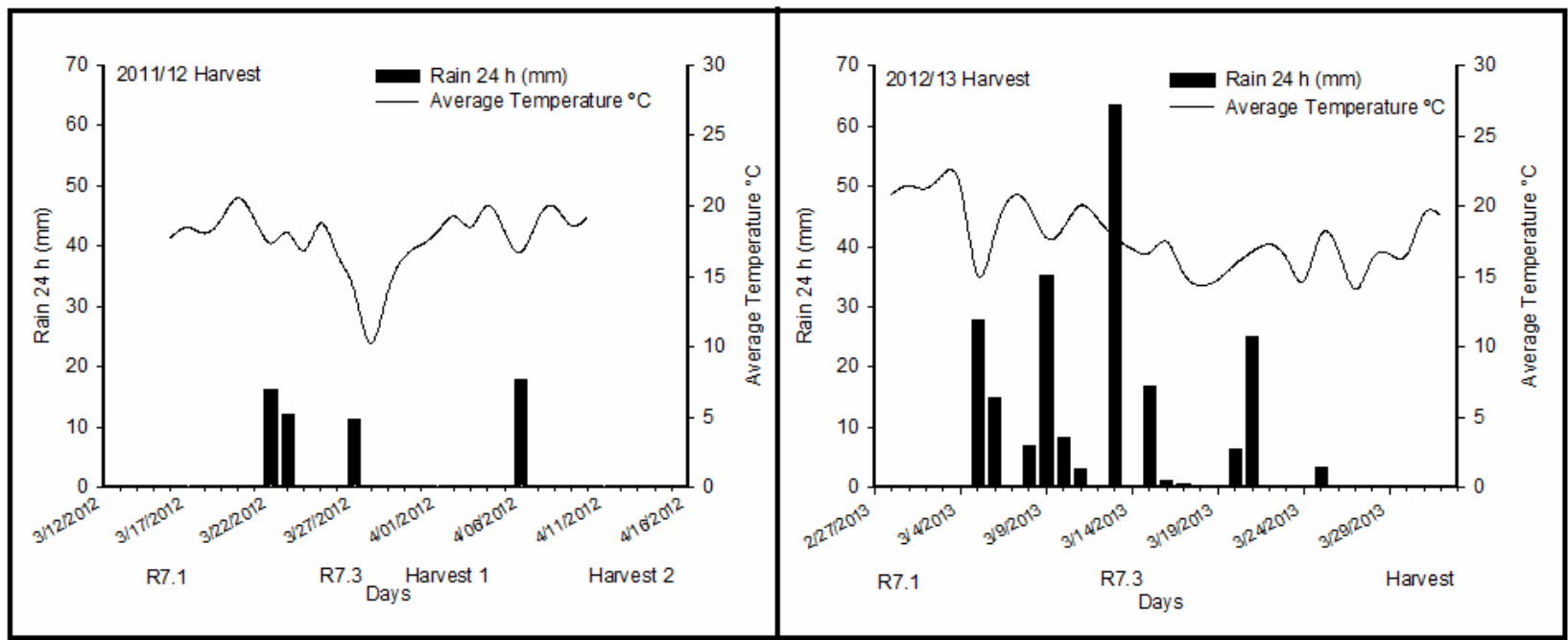

Source: Meteorological data of Campos Novos, SC from Epagri/Ciram (2014).

Crop 1: crop of the plots treated with desiccants glufosinate-ammonium and paraquat applied to stage R7.1 of the $2011 / 12$ harvest; Crop 2: crop of the plots treated with desiccant carfentrazone-ethyl applied to stage R7.1 stage of the $2011 / 12$ harvest, and of all desiccants applied to stage R7.3 and control. Crop: crop of all treatments of the 2012/13 harvest.

Figure 1 - Rain (mm) and average temperature $\left({ }^{\circ} \mathrm{C}\right)$ recorded in 2011/12 and 2012/13 harvests, corresponding to the application stages of the desiccants (R7.1 and R7.3) until the crop of the soybean plants, Campos Novos, SC.

desiccants be conducted from March to April, where the likelihood of rain in preharvest is lower, since the plants are at stage R7.1.

It is concluded that desiccation can be an alternative to the early soybean harvesting, but it depends on the cultivar, time of application and the active principle of the desiccant and the absence of rains in preharvest. With the use of glufosinate-ammonium and paraquat desiccants, in stage R7.1 of the plants, in the 2011/12 harvest, seeds viability and vigor were maintained, and this maintenance was dependent on the cultivar.

\section{ACKNOWLEDGMENTS}

To cooperative Coaccer, Copercampos and Epagri, for making available the area and the machines, and to the company FMC, for donating herbicide Aurora.

For the scholarship granted to the first author by the FUMDES program, the Santa Catarina Education Department, and UNOESC, for releasing during the doctoral period.

To CNPQ (Conselho Nacional de Desenvolvimento Científico e Tecnológico;
National Counsel of Technological and Scientific Development) and FAPESC (Fundação de Amparo à Pesquisa e Inovação do Estado de Santa Catarina; Foundation for Support to Research and Innovation of the state of Santa Catarina), for the financial support to the project.

For the productivity scholarship (PQ-2) granted to the second author (CMMC) by CNPQ.

\section{LITERATURE CITED}

\section{ASSOCIAÇÃO DE PRODUTORES DE SEMENTES E MUDAS DO ESTADO DE SANTA CATARINA- APROSESC. Estatística. Canoinhas: 2014.}

BENNETT, A.; SHAW, D. R. Effect of preharvest desiccants on Group IV Glycine max seed viability. Weed Sci., v. 48, n. 4, p. 426-430, 2000

BRASIL. Ministério da Agricultura, Pecuária e Abastecimento. Instrução Normativa no 45 de 17 de dezembro de 2013. Brasília: 2013.

BRASIL. Ministério da Agricultura, Pecuária e Abastecimento. Regras para análise de sementes. Brasília: 2009. 
BULOW, R. L.; CRUZ-SILVA, C. T. A. Dessecantes aplicados na pré-colheita na qualidade fisiológica de sementes de soja. J. Agron. Sci., v. 1, n. 1, p. 67-75, 2012.

COMISSÃO DE QUÍMICAE FERTILIDADE DO SOLORS/SC CQFS-RS/SC. Manual de adubação e de calagem para os Estados do Rio Grande do Sul e de Santa Catarina. 10.ed. Porto Alegre: Sociedade Brasileira de Ciência do Solo, 2004. 400 p.

DALTRO, E. M. F. et al. Aplicação de dessecantes em pré-colheita: efeito na qualidade fisiológica de sementes de soja. R. Bras. Sementes, v. 32, n. 1, p. 111-122, 2010.

DAYAN, F. E. Selectivity and mode of action of carfentrazone, a novel phenyl triazolinone herbicide. Pest. Manag. Sci., v. 51, n. 1, p. 65-73, 1997.

DINIZ, F. O. Physiological quality of soybean seeds of cultivars submitted to harvesting delay and its association with seedling emergence in the field.

J. Seed Sci., v. 35, n. 2, p. 147-152, 2013.

DUFLOTH, J. H. et al. Estudos básicos regionais de Santa Catarina. Florianópolis: Epagri, 2005. 101 p.

EMPRESA BRASILEIRA DE PESQUISA AGROPECUÁRIA-EMBRAPA. Indicações técnicas para a cultura da soja no Rio Grande do Sul e em Santa Catarina, safras 2012/2013 e 2013/2014. Passo Fundo: Embrapa Trigo, 2012. 142 p. (Documentos, 107)

EMPRESADE PESQUISAAGROPECUÁRIAE EXTENSÃORURAL/CENTRODE INFORMAÇÕES DE RECURSOS AMBIENTAIS E DE HIDROMETEOROLOGIA-EPAGRI/CIRAM. Monitoramento meteorológico. Florianópolis: 2014.

FRANÇANETO, J. B.; HENNING, A. A. Qualidade fisiológica e sanitária de sementes de soja. Londrina: EMBRAPA-CNPSo, 1984. 39 p. (Circular Técnica, 9)

FRANÇA NETO, J. B. et al. O teste de tetrazólio em sementes de soja. Londrina: EMBRAPA-CNPSo, 1998. 72 p. (Documentos, 116)

GIURIZATTO, M. I. K. et al. Efeito da época de colheita e da espessura do tegumento sobre a viabilidade e o vigor de sementes de soja. Ci. Agrotec., v. 27, n. 4, p. 771-779, 2003.
GUIMARÃES, V. F et al. Produtividade e qualidade de sementes de soja em função de estádios de dessecação e herbicidas. Planta Daninha, v. 30, n. 4, p. 567-573, 2012.

GRIFFIN, J. L. et al. Herbicides as harvest aids. Weed Sci., v. 58, n. 1, p. 355-358, 2010.

INOUE, M. H. et al. Rendimento de grãos e qualidade de sementes de soja após a aplicação de herbicidas dessecantes. Ci. Rural, v. 1, n. 4, p. 71-83, 2003.

KRZYZANOWSKI, F. C. et al. Vigor de sementes: conceitos e testes. Londrina: ABRATES, 1999. $218 \mathrm{p}$.

LACERDA, A. L. S. et al. Efeitos da dessecação de plantas de soja no potencial fisiológico e sanitário das sementes. Bragantia, v. 64, n. 3, p. 447-457, 2005.

LAMEGO, F. P. et al. Dessecação pré colheita e efeitos sobre a produtividade e qualidade fisiológica de sementes. Planta Daninha, v. 31, n. 1, p. 929-938, 2013.

RATNAYARE, S.; SHAWN, D. R. Effects of harvest-aid herbicides on soybean (Glycine max) seed yield and quality. Weed Technol., v. 6, n. 6, p. 339-344, 1992.

RITCHIE, S. et al. How a soybean plant develops. Ames: Iowa State University of Science and Technology, 1982. $20 \mathrm{p}$.

SAS. SAS Institute Inc ${ }^{\circledR}$ 2009. Cary, NC: USA, Licence UDESC, 2009.

SCHEEREN, B. R. et al. Qualidade fisiológica e produtividade de sementes de soja. R. Bras. Sementes, v. 32, n. 3, p. 35-41, 2010.

WHIGHAM, D. K.; STOLLER, E. W. Soybean desiccation by paraquat, glyphosate, and ametryn to accelerate harvest. Agron. J., v. 1, n. 71, p. 630-633, 1979.

ZAGONEL, J. Herbicide application timing in preharvest desiccation of soybean cultivars with different growth habits. J. Environ. Sci. Health, v. 1, n. 40, p. 13-20, 2005. 